\title{
Winogradskyella exilis sp. nov., isolated from the starfish Stellaster equestris, and emended description of the genus Winogradskyella
}

Correspondence

Elena P. Ivanova

eivanova@swin.edu.au
Elena P. Ivanova, ${ }^{1,2}$ Richard Christen, ${ }^{3}$ Nataliya M. Gorshkova, ${ }^{2}$ Natalia V. Zhukova, ${ }^{4}$ Valeriya V. Kurilenko, ${ }^{2}$ Russell J. Crawford ${ }^{1}$ and Valery V. Mikhailov ${ }^{2}$

\footnotetext{
${ }^{1}$ Swinburne University of Technology, Faculty of Life and Social Sciences, PO Box 218, Hawthorn, Victoria 3122, Australia

${ }^{2}$ Pacific Institute of Bioorganic Chemistry of the Far-Eastern Branch of the Russian Academy of Sciences, Pr. 100 Let Vladivostoku 159, 690022 Vladivostok, Russian Federation

${ }^{3}$ CNRS, UMR 6543, Laboratoire de Biologie Virtuelle, Parc Valrose, F-06108 Nice, France

${ }^{4}$ Institute of Marine Biology of the Far-Eastern Branch of the Russian Academy of Sciences, 690041 Vladivostok, Russian Federation
}

A pale-yellowish-pigmented strain, $022-2-26^{\top}$, was isolated from a starfish, Stellaster equestris. Cells of strain $022-2-26^{\top}$ were Gram-negative short rods that were chemo-organotrophic, alkalitolerant and mesophilic. The predominant menaquinone was MK-6. The major cellular fatty acids were iso- $\mathrm{C}_{15: 0}$, iso- $\mathrm{C}_{15: 1}, \mathrm{C}_{15: 0}$, iso- $\mathrm{C}_{15: 0} 2-\mathrm{OH}$ and iso- $\mathrm{C}_{17: 0} 3-\mathrm{OH}$ (together representing $87 \%$ of the total fatty acids). The DNA G $+\mathrm{C}$ content was $30.1 \mathrm{~mol} \%$. A $16 \mathrm{~S}$ rRNA gene sequence of the isolate was determined and phylogenetic analyses revealed that strain 022$2-26^{\top}$ formed a robust clade (neighbour-joining algorithm with a bootstrap value of $95 \%$ and parsimony and maximum-likelihood algorithms) with type strains of species in the genus Winogradskyella. The closest phylogenetic neighbour of strain $022-2-26^{\top}$ was Winogradskyella poriferorum UST030701-295 ${ }^{\top}$ (96 \% 16S rRNA gene sequence similarity; 59 differences between sequences). On the basis of the phenotypic and chemotaxonomic characteristics and the phylogenetic evidence, it is proposed that strain $022-2-26^{\top}$ represents a novel species, Winogradskyella exilis sp. nov. The type strain is $022-2-26^{\top}\left(=\mathrm{KMM}^{\top} 6013^{\top}=\mathrm{CIP} 109976^{\top}\right)$.
The genus Winogradskyella was created within the family Flavobacteriaceae in 2005 to accommodate three species, Winogradskyella thalassocola, W. epiphytica and W. eximia, marine bacteria respectively isolated from the green alga Acrosiphonia sonderi and the brown algae Chorda filum and Laminaria japonica (Nedashkovskaya et al., 2005). A fourth species was described shortly afterwards: Winogradskyella poriferorum, isolated from a sponge (Lau et al., 2005). We report here the polyphasic characterization of a novel bacterium isolated from the starfish Stellaster equestris.

The starfish was collected with dragging equipment in October 1998 at a depth of $100 \mathrm{~m}\left(30 \%\right.$ salinity, $\left.15{ }^{\circ} \mathrm{C}\right)$ in the South China Sea $\left(26^{\circ} 28.3^{\prime} \mathrm{N} 122^{\circ} 29.0^{\prime} \mathrm{E}\right)$. The starfish

Abbreviation: FAME, fatty acid methyl ester.

The GenBank/EMBL/DDBJ accession number for the 16S rRNA gene sequence of strain $022-2-26^{\top}$ is FJ595484.

A table of fatty acid compositions and a 16S rRNA gene sequencebased consensus tree are available as supplementary material with the online version of this paper. was pre-rinsed in sterilized seawater and a piece (about $3 \mathrm{~g}$ ) of tegument tissue was removed aseptically. Strain $022-2-26^{\mathrm{T}}$ was isolated from the tissue homogenates by plating samples $(0.1 \mathrm{ml})$ on agar plates of marine agar 2216 (MA; Oxoid) and on medium B. Medium B contained (w/v) $0.2 \%$ Bacto peptone (Difco), $0.2 \%$ casein hydrolysate (Merck), $0.2 \%$ Bacto yeast extract (Oxoid), $0.1 \%$ glucose, $0.02 \% \mathrm{KH}_{2} \mathrm{PO}_{4}, 0.005 \% \mathrm{MgSO}_{4} .7 \mathrm{H}_{2} \mathrm{O}$ and $1.5 \%$ Bacto agar (Oxoid) in $50 \%(\mathrm{v} / \mathrm{v})$ natural seawater and $50 \%(\mathrm{v} / \mathrm{v})$ distilled water at $\mathrm{pH} 7.5-7.8$, as described elsewhere (Ivanova et al., 1996).

The phenotypic properties used for the characterization of Flavobacterium species were determined by using standard procedures (Smibert \& Krieg, 1994) and as described elsewhere (McMeekin et al., 1971; Ivanova et al., 1996, 1998, 2005; Bernardet et al., 2002). Strain 022-2-26 ${ }^{\mathrm{T}}$ was cultured at $22-24{ }^{\circ} \mathrm{C}$. To test for spreading growth and gliding motility, strain $022-2-26^{\mathrm{T}}$ was grown on medium $\mathrm{B}$ with the peptone content reduced to $0.02 \%\left(0.2 \mathrm{~g} \mathrm{l}^{-1}\right)$. Gliding motility was verified by using phase-contrast 
microscopy (Eclipse TE-DH, $100 \mathrm{~W}$; Nikon) of hangingdrop preparations. The bathochromic shift test with $20 \%$ $(\mathrm{w} / \mathrm{v}) \mathrm{KOH}$ was performed to detect flexirubin pigments (Fautz \& Reichenbach, 1980). The following physiological and biochemical properties of strain $022-2-26^{\mathrm{T}}$ were examined: oxidation/fermentation of glucose (Hugh \& Leifson, 1953), Gram stain, reduction of nitrate and nitrite, liquefaction of gelatin, activity of catalase (with $5 \% \mathrm{H}_{2} \mathrm{O}_{2}$ ), oxidase (Kóvacs, 1956), arginine dihydrolase, lysine decarboxylase and ornithine decarboxylase, production of poly- $\beta$-hydroxybutyrate, acetoin (Voges-Proskauer test), indole and $\mathrm{H}_{2} \mathrm{~S}$, requirement for sodium ions $(0,1,3,6,8$, $10,12,15 \%, w / v, \mathrm{NaCl}$ ) in nutrient broth (Oxoid) and hydrolysis of agar, alginate, casein, chitin, DNA, starch and Tween 80 . The temperature range for growth was examined on MA at $4,10,30,35,37$ and $42{ }^{\circ} \mathrm{C}$. Other physiological and biochemical tests were performed with the API 20E, API 50 and API ZYM systems (bioMérieux). Susceptibility to antibiotics was tested by the diffusion plate technique, using solid medium B and discs impregnated with the following antibiotics ( $\mu \mathrm{g}$ per disc unless otherwise indicated): ampicillin (10), benzylpenicillin (10 U), carbenicillin (100), cephalexin (30), cephazolin (30), chloramphenicol (30), erythromycin (15), gentamicin (10), kanamycin (30), lincomycin (15), nalidixic acid (30), neomycin (30), ofloxacin (5), oleandomycin (15), oxacillin (10), polymyxin (300 U), rifampicin (5), streptomycin (30) and tetracycline (30). The physiological and biochemical characteristics are presented in the species description and in Table 1.

For the extraction and characterization of carotenoid pigments and menaquinones, phospholipids and fatty acids, cell biomass of strain $022-2-26^{\mathrm{T}}$ was harvested from MA (five plates for carotenoid pigment analysis) after incubation at $28{ }^{\circ} \mathrm{C}$ for $48 \mathrm{~h}$ as described previously (Ivanova et al., 2005). Pigment extraction and characterization was performed as described previously (Ivanova et al., 2005). The isoprenoid quinone composition was characterized by HPLC-MS (model 1200L; Varian) using a reversed-phase Omnisphere $3 \mathrm{C} 18$ column $(20 \mathrm{~cm} \times$ $2 \mathrm{~mm}$; Varian) at $55^{\circ} \mathrm{C}$ and acetonitrile as the mobile

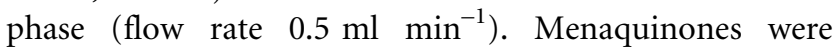
detected at $270 \mathrm{~nm}$. Lipids were extracted according to Bligh \& Dyer (1959). Polar lipids were separated and identified as described previously (Ivanova et al., 2005). The lipids were treated with $5 \% \mathrm{HCl}$ in methanol at $80{ }^{\circ} \mathrm{C}$ for $180 \mathrm{~min}$ to produce fatty acid methyl esters (FAMEs; Christie, 1982). FAMEs were analysed by GC with flame ionization detection (Shimadzu GC-17) with a fused silica capillary column $(30 \mathrm{~m} \times 0.25 \mathrm{~mm})$ coated with Supelcowax 10 at $210{ }^{\circ} \mathrm{C}$. Helium was used as the carrier gas. FAMEs were identified by comparing the retention times with those of authentic standards and using equivalent chain-length measurements. To ensure correct identification, FAMEs were analysed by GC-MS using a model GCMSQP5050A (Shimadzu) fitted with an MDN-5S capillary column $(30 \mathrm{~m} \times 0.25 \mathrm{~mm})$. The column temperature was
Table 1. Characteristics that differentiate strain $022-2-26^{\top}$ from the type strains of the most closely related Winogradskyella species

Strains: 1 , Winogradskyella exilis sp. nov. $022-2-26^{\mathrm{T}} ; 2, W$. thalassocola KMM $3907^{\mathrm{T}}$; 3, W. epiphytica KMM $3906^{\mathrm{T}}$; 4, W. eximia KMM $3944^{\mathrm{T}}$; 5 , W. poriferorum UST030701-295 ${ }^{\mathrm{T}}$. Data were obtained in this study or from Lau et al. (2005) and Nedashkovskaya et al. (2005). All strains were positive for aerobic and facultatively anaerobic metabolism, gliding motility, catalase and alkaline phosphatase activities and hydrolysis of gelatin and Tween 40. All strains were negative for the presence of flexirubin pigments, $\beta$-galactosidase activity, hydrolysis of cellulose (CM-cellulose and filter paper) and chitin, production of indole, acetoin and $\mathrm{H}_{2} \mathrm{~S}$ and utilization of citrate, D-adonitol, L-arabinose, dulcitol, D-galactose, inositol, lactose, melibiose, D-rhamnose, D-sorbitol and D- and L-xylose. +, Positive; W, weakly positive; -, negative.

\begin{tabular}{|lccccc|}
\hline Characteristic & $\mathbf{1}$ & $\mathbf{2}$ & $\mathbf{3}$ & $\mathbf{4}$ & $\mathbf{5}$ \\
\hline Ranges for growth & & & & & \\
Temperature $\left({ }^{\circ} \mathrm{C}\right)$ & $5-35$ & $12-44$ & $4-37$ & $4-33$ & $4-33$ \\
NaCl $(\%, \mathrm{w} / \mathrm{v})$ & $0-6$ & $1-4$ & $1-8$ & $1-5$ & $1-8$ \\
Oxidase & - & + & + & + & + \\
Urease & $\mathrm{W}$ & - & - & - & - \\
Denitrification & + & - & - & - & - \\
Degradation of: & & & & & \\
Agar & - & - & + & + & + \\
Casein & - & - & - & + & - \\
DNA & - & + & + & - & - \\
Starch & W & - & - & + & - \\
Tween 80 & - & + & + & - & - \\
Utilization of: & & & & & \\
Cellobiose & - & - & - & - & + \\
D-Glucose & - & - & - & + & + \\
Maltose & - & - & - & + & + \\
D-Mannitol & - & - & - & + & - \\
D-Mannose & - & - & - & + & + \\
Sucrose & - & - & - & + & + \\
DNA G+C content & 30.2 & 32.8 & 35.2 & 36.1 & 34.6 \\
(mol\%) & & & & & \\
\hline
\end{tabular}

programmed for a hold at $170{ }^{\circ} \mathrm{C}$ for $1 \mathrm{~min}$, an increase to $240{ }^{\circ} \mathrm{C}$ at $2{ }^{\circ} \mathrm{C} \mathrm{min}{ }^{-1}$ and a hold at $240{ }^{\circ} \mathrm{C}$ for $20 \mathrm{~min}$. The temperature of the injector and detector were $250{ }^{\circ} \mathrm{C}$. The results of the fatty acid analysis are presented in the species description and Supplementary Table S1 (available in IJSEM Online). Strain 022-2-26 ${ }^{\mathrm{T}}$ contained MK-6, which is the characteristic respiratory quinone for the family Flavobacteriaceae, and high levels of branched and hydroxy $\mathrm{C}_{15}$ and $\mathrm{C}_{17}$ fatty acids (representing $92.9 \%$ of the total fatty acid content), which are typical fatty acids for the family Flavobacteriaceae (Bowman et al., 1998).

Genomic DNA was extracted from strain $022-2-26^{\mathrm{T}}$ following the method of Marmur (1961) and the G+C content of the DNA was determined by the thermal denaturation method of Marmur \& Doty (1962). The $\mathrm{G}+\mathrm{C}$ content of the DNA was $30.1 \pm 0.2 \mathrm{~mol} \%$. The $16 \mathrm{~S}$ 
rRNA gene was amplified and sequenced at the laboratories of the Australian Genome Research Facility, Brisbane, Australia. Briefly, the PCR primers corresponded to Escherichia coli positions 5 and 1540. The amplification products were purified using Microcon 100 molecularmass cut-off membranes (Millipore) and checked for quality and quantity on separation on agarose gel. Cycle sequencing of the amplification products was performed using AmpliTaq ES DNA polymerase and rhodamine dye terminators and the sequencing reaction products were analysed with an ABI Prism 377 DNA Sequencer (Applied Biosystems).

The 16S rRNA gene sequence of strain $022-2-26^{\mathrm{T}}$ was compared against a database of cultured species (http:// bioinfo.unice.fr/blast) and type strains (EzTaxon; http:// 147.47.212.35:8080) in order to retrieve the 110 most similar sequences. A multiple sequence alignment was performed using CLUSTAL W version 2 (Larkin et al., 2007) and checked manually with SeaView (Galtier et al., 1996). Domains common to all sequences were used to derive a preliminary phylogenetic tree (not shown) using the most recent version of SeaView (version 4; Gouy et al., 2010) and the BioNJ neighbour-joining algorithm (Gascuel, 1997). This tree showed that strain $022-2-26^{\mathrm{T}}$ was most closely related to strains in the genus Winogradskyella. According to the preliminary tree, the 44 sequences most closely related to strain $022-2-26^{\mathrm{T}}$ were selected and the alignment was checked again. Positions containing insertions or deletions were excluded. A full phylogenetic analysis was undertaken using the BioNJ, parsimony and maximumlikelihood algorithms, according to Gascuel (1997), PHYLIP version 3.52 and PhyML version 3.0.1 (Guindon \& Gascuel, 2003), respectively. For the neighbour-joining analysis, a distance matrix was calculated using Kimura's two-parameter correction and bootstraps were performed using 1000 replications. Phylogenetic trees were drawn using TreeDyn (Chevenet et al., 2006) or SeaView. A consensus phylogenetic tree is shown in Supplementary Fig. S1. Notably, when using similarity values only, the closest neighbour to strain $022-2-26^{\mathrm{T}}$ was $W$. poriferorum UST030701-295 ${ }^{\mathrm{T}}$, with which the isolate showed a similarity of about $96 \%$ (59 differences between sequences) and formed a robust cluster with all algorithms and a bootstrap value of $82 \%$ (Fig. 1). Strain $022-2-26^{\mathrm{T}}$ was also robustly included in the clade formed by the type strains of Winogradskyella species (all methods, bootstrap value of $95 \%)$. Thus, the phylogenetic analyses provide strong evidence that strain $022-2-26^{\mathrm{T}}$ represents a novel species of the genus Winogradskyella.

Strain $022-2-26^{\mathrm{T}}$ can be differentiated easily from the type strains of previously described species of the genus Winogradskyella. For example, strain $022-2-26^{\mathrm{T}}$ does not have a requirement for $\mathrm{NaCl}$ for growth and it is negative for oxidase and positive for denitrification. However, the fatty acid profile of strain $022-2-26^{\mathrm{T}}$ is characteristic of the genus Winogradskyella, members of which have levels of iso- $\mathrm{C}_{15: 0} 2-\mathrm{OH}$ and iso- $\mathrm{C}_{17: 0} 3-\mathrm{OH}$ ranging from 4.2 to $10.2 \%$ and distinct proportions of iso- $\mathrm{C}_{15: 0}$ and iso- $\mathrm{C}_{15: 1}$ as the major fatty acids. Consequently, we consider that strain $022-2-26^{\mathrm{T}}$ represents a novel species in the genus Winogradskyella, for which the name Winogradskyella exilis sp. nov. is proposed.

\section{Emended description of the genus Winogradskyella Nedashkovskaya et al. 2005}

The description is as given by Nedashkovskaya et al. (2005) with the following amendments. Some strains are oxidasenegative and able to reduce nitrate. Some strains do not require $\mathrm{NaCl}$ for growth.

\section{Description of Winogradskyella exilis sp. nov.}

Winogradskyella exilis (e.xi'lis. L. fem. adj. exilis small, thin, slender).

Rod-shaped cells with slightly irregular sides and pointed ends, about $0.8-1.8 \mu \mathrm{m}$ long and $0.4-0.9 \mu \mathrm{m}$ wide. Gramnegative. No endospores or resting stages. Exhibits gliding motility. Does not accumulate poly- $\beta$-hydroxybutyrate as an intracellular reserve product or have an arginine dihydrolase system. Aerobic and facultatively anaerobic. Anaerobic growth occurs by fermentation of D-glucose or anaerobic respiration of nitrate. Chemo-organotrophic. Oxidase-negative and catalase-positive. Colonies are light yellow, circular, 1-3 $\mathrm{mm}$ in diameter and low convex on solid media with a high content of nutrient components. Produces carotenoid pigments with absorbance peaks at 455 and $480 \mathrm{~nm}$. Does not produce flexirubin pigments.

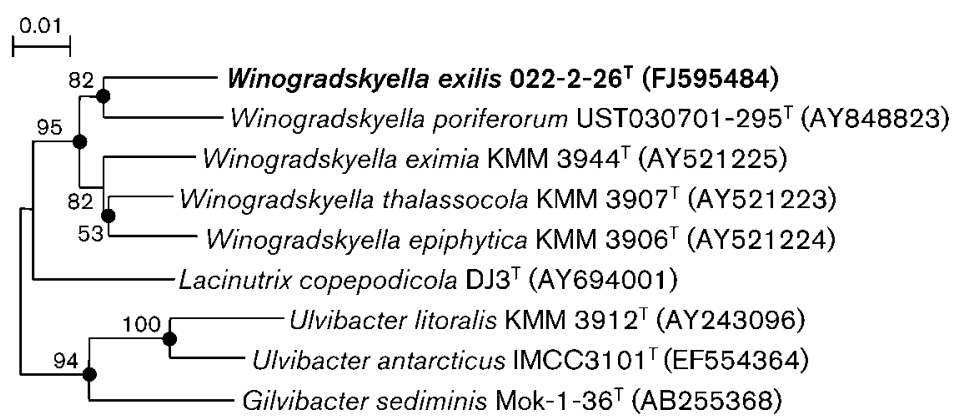

Fig. 1. Unrooted neighbour-joining phylogenetic tree showing the position of strain 022-2$26^{\top}$ among its closest phylogenetic neighbours, based on 16S rRNA gene sequences. Bootstrap values $(>50 \%)$ based on 1000 replications are shown at branch nodes. Filled circles indicate that the corresponding nodes were also recovered in trees constructed with both the maximum-likelihood and parsimony algorithms. Bar, 0.01 substitutions per nucleotide position. 
Grows optimally at $23{ }^{\circ} \mathrm{C}$; no growth at 4 or $37{ }^{\circ} \mathrm{C}$. Grows at $\mathrm{pH}$ 6.0-10.0 (optimum $\mathrm{pH} 8.0-8.5$ ) and with $0-6 \%$ $\mathrm{NaCl}$. Weakly hydrolyses starch and gelatin. Does not decompose agar or chitin. Produces alkaline phosphatase, esterase (C4), esterase lipase (C8), leucine arylamidase and valine arylamidase. With the API 50 system, utilizes only potassium 5-ketogluconate. Susceptible to ( $\mu \mathrm{g}$ per disc unless otherwise indicated) ampicillin (10), benzylpenicillin (10 U), carbenicillin (100), cephalexin (30), cephazolin (30), chloramphenicol (30), lincomycin (15), nalidixic acid (30), ofloxacin (5), oleandomycin (15), rifampicin (5) and tetracycline (30), but not to erythromycin (15), gentamicin (10), kanamycin (30), neomycin (30), oxacillin (10), polymyxin $(300 \mathrm{U})$ or streptomycin (30). The main cellular fatty acids are iso- $\mathrm{C}_{15: 0}$, iso- $\mathrm{C}_{15: 1}, \mathrm{C}_{15: 0}$, iso$\mathrm{C}_{15: 0} 2-\mathrm{OH}$ and iso- $\mathrm{C}_{17: 0}$ 3-OH. Phosphatidylethanolamine is the only phospholipid detected; aminolipids are not detected. The major isoprenoid quinone is MK-6. The DNA G $+C$ content of the type strain is $30.0 \pm 0.2 \mathrm{~mol} \%$.

The type strain is $022-2-26^{\mathrm{T}}\left(=\mathrm{KMM} \quad 6013^{\mathrm{T}}=\mathrm{CIP}\right.$ $109976^{\mathrm{T}}$ ), isolated from the starfish Stellaster equestris.

\section{Acknowledgements}

The authors are grateful to Dr A. M. Lysenko for help with the genetic analysis. This study was partially supported by funds from the Australian Research Council, the RFBR (grant no. 08-04-0009), the Presidium and FEB RAS (grant no. 09-III-A-06-227) and State Contract 02.518.11.7169 from the Ministry for Education and Science of the Russian Federation.

\section{References}

Bernardet, J.-F., Nakagawa, Y. \& Holmes, B. (2002). Proposed minimal standards for describing new taxa of the family Flavobacteriaceae and emended description of the family. Int J Syst Evol Microbiol 52, 1049-1070.

Bligh, E. G. \& Dyer, W. J. (1959). A rapid method for total lipid extraction and purification. Can J Biochem Physiol 37, 911-917.

Bowman, J. P., McCammon, S., Lewis, T., Skerratt, J. H., Brown, J. L., Nichols, D. S. \& McMeekin, T. A. (1998). Psychroflexus torquis gen. nov., sp. nov., a psychrophilic species from Antarctic sea ice, and reclassification of Flavobacterium gondwanense (Dobson et al. 1993) as Psychroflexus gondwanense gen. nov., comb. nov. Microbiology 144, 1601-1609.

Chevenet, F., Brun, C., Banuls, A. L., Jacq, B. \& Christen, R. (2006). TreeDyn: towards dynamic graphics and annotations for analyses of trees. Bioinformatics 7, 439.

Christie, W. W.(1982). In Lipid Analysis. Isolation, Separation, Identification and Structural Analysis of Lipids, 2nd edn, p. 55. Oxford: Pergamon Press.

Fautz, E. \& Reichenbach, H. (1980). A simple test for flexirubin-type pigments. FEMS Microbiol Lett 8, 87-91.

Galtier, N., Gouy, M. \& Gautier, C. (1996). SeaView and PHYLO_WIN: two graphic tools for sequence alignment and molecular phylogeny. Comput Appl Biosci 12, 543-548.
Gascuel, O. (1997). BIONJ: an improved version of the NJ algorithm based on a simple model of sequence data. Mol Biol Evol 14, 685695.

Gouy, M., Guindon, S. \& Gascuel, O. (2010). SeaView version 4: a multiplatform graphical user interface for sequence alignment and phylogenetic tree building. Mol Biol Evol 27, 221-224.

Guindon, S. \& Gascuel, O. (2003). A simple, fast, and accurate algorithm to estimate large phylogenies by maximum likelihood. Syst Biol 52, 696-704.

Hugh, R. \& Leifson, E. (1953). The taxonomic significance of fermentative versus oxidative metabolism of carbohydrates by various Gram-negative bacteria. J Bacteriol 66, 24-26.

Ivanova, E. P., Kiprianova, E. A., Mikhailov, V. V., Levanova, G. F., Garagulya, A. D., Gorshkova, N. M., Yumoto, N. \& Yoshikawa, S. (1996). Characterization and identification of marine Alteromonas nigrifaciens strains and emendation of the description. Int J Syst Bacteriol 46, 223-228.

Ivanova, E. P., Kiprianova, E. A., Mikhailov, V. V., Levanova, G. F., Garagulya, A. D., Gorshkova, N. M., Vysotskii, M. V., Nicolau, D. V., Yumoto, Y. \& Yoshikawa, S. (1998). Phenotypic diversity of Pseudoalteromonas citrea from different marine habitats and emendation of the description. Int J Syst Bacteriol 48, 247-256.

Ivanova, E. P., Bowman, J. P., Lysenko, A. M., Zhukova, N. V., Gorshkova, N. M., Kuznetsova, T. A., Kalinovskaya, N. I., Shevchenko, L. S. \& Mikhailov, V. V. (2005). Erythrobacter vulgaris sp. nov., a novel organism isolated from the marine invertebrates. Syst Appl Microbiol 28, 123-130.

Kóvacs, N. (1956). Identification of Pseudomonas pyocyanea by the oxidase reaction. Nature 178, 703.

Larkin, M. A., Blackshields, G., Brown, N. P., Chenna, R., McGettigan, P. A., McWilliam, H., Valentin, F., Wallace, I. M., Wilm, A. \& other authors (2007). CLUSTAL $W$ and CLUSTAL X version 2.0. Bioinformatics 23, 2947-2948.

Lau, S. C. K., Tsoi, M. M. Y., Li, X., Plakhotnikova, I., Dobretsov, S., Lau, K. W. K., Wu, M., Wong, P.-K., Pawlik, J. R. \& Qian, P.-Y. (2005). Winogradskyella poriferorum sp. nov., a novel member of the family Flavobacteriaceae isolated from a sponge in the Bahamas. Int J Syst Evol Microbiol 55, 1589-1592.

Marmur, J. (1961). A procedure for the isolation of deoxyribonucleic acid from microorganisms. J Mol Biol 3, 208-218.

Marmur, J. \& Doty, P. (1962). Determination of the base composition of deoxyribonucleic acid from its thermal denaturation temperature. J Mol Biol 5, 109-118.

McMeekin, T. A., Patterson, J. T. \& Murray, J. G. (1971). An initial approach to the taxonomy of some gram negative yellow pigmented rods. J Appl Bacteriol 34, 699-716.

Nedashkovskaya, O. I., Kim, S. B., Han, S. K., Snauwaert, C., Vancanneyt, M., Swings, J., Kim, K.-O., Lysenko, A. M., Rohde, M. \& other authors (2005). Winogradskyella thalassocola gen. nov., sp. nov., Winogradskyella epiphytica sp. nov. and Winogradskyella eximia sp. nov., marine bacteria of the family Flavobacteriaceae. Int J Syst Evol Microbiol 55, 49-55.

Smibert, R. M. \& Krieg, N. R. (1994). Phenotypic characterization. In Methods for General and Molecular Bacteriology, pp. 607-654. Edited by F. Gerhardt, R. G. E. Murray, W. A. Wood \& N. R. Krieg. Washington, DC: American Society for Microbiology. 